\title{
Medicinal plants with reported anxiolytic and sedative activities in Nigeria: A systematic review
}

\author{
Abdullahi Rabiu Abubakar' (1), Mainul Haque² (D) \\ 'Department of Pharmacology and Therapeutics, Faculty of Pharmaceutical Sciences, Bayero University, 700233 Kano, Nigeria \\ ${ }^{2}$ Unit of Pharmacology, Faculty of Medicine and Defence Health, National Defence University of Malaysia, Kem Sungai \\ Besi, 57000 Kuala Lumpur, Malaysia
}

ORCID IDs of the authors: A.R.A. 0000-0002-9740-7856; M.H. 0000-0002-6124-7993.

Cite this article as: Abubakar AR, Haque M (2019). Medicinal plants with reported anxiolytic and sedative activities in Nigeria: A systematic review. Istanbul J Pharm 49 (2): 92-104.

\begin{abstract}
Medicinal plants have been widely used in folklore medicine in the treatment of various diseases such as mental and neurological disorders. Mental disorders like anxiety and depression are very common among Nigerian populace. The purpose of this review was to access and evaluate several articles published on the anxiolytic and sedative properties of medicinal plants in Nigeria and to find out the gaps left for further research and drug development. Eighty-two publications available among Nigerian Universities and Research Institutes between 2008 and 2018 were selected. Seven electronic databases such as Nigerian Plant Database, HerbMed, AGRICOLA, MedlinePlus, PubMed, ScienceDirect, and Springer-Link were thoroughly explored from which 226 relevant articles were obtained using Google Scholar, Hotbot and FreeFullPdf as search engines. A number of studies conducted to test for the anxiolytic and sedative activity of medicinal plants in Nigeria were included. Articles published between 2008 and 2018 were selected. The studies were conducted in Nigeria. Research carried out before 2008 was not selected. All publications with authorship outside Nigeria were excluded. Several medicinal plants on which experiments were conducted were reported to have anxiolytic and or sedative properties in Nigeria. Several medicinal plants have shown promise as anxiolytic and sedative agents in laboratory animals' studies. The majority of these plants were used traditionally in the past to treat anxiety in Nigeria. Further research on the efficacy and safety of these medicinal plants could yield a more cost effective and perhaps safer alternative in the treatment of anxiety among Nigerians.
\end{abstract}

Keywords: Anxiolytic, sedative, medicinal-plants, phytotheraphy, Nigeria

\section{INTRODUCTION}

Herbal medicine has played a vital role in the phytotheraphy of various ailments including central nervous system disorders. Various part of the plants such as leaves, stems, roots, fruits, seeds, flowers etc. were used by both traditional and orthodox medicine practitioners as their source of medicaments (Magaji et al., 2008; Akindele and Adeyemi, 2010; Onasanwo et al., 2010; Egharevba et al., 2015; Adebiyi et al., 2016). The application of medicinal plants in the treatment of mental and neurological disorders has been documented over decades. Categorically, medicinal plants comprising secondary metabolites such as alkaloids, tannins, saponnins, flavonoids and sterols are highly associated with anxiolytic and sedative activities (Magaji et al., 2008; Asuquo et al., 2013; Edewor-Kuponiyi, 2013; Tijjani et al., 2014; Rungsung et al., 2015; Adebiyi et al., 2016). In addition, orthodox medicines available such as benzodiazepines are commonly associated with physical dependence, day time fatigue, tolerance and cognitive impairment. As such, there is need to search for medicinal plants that are capable of alleviating mental disorders without many side effects (Onasanwo et al., 2010; Edewor-Kuponiyi, 2013; Magaji et al., 2015).

Anxiety belongs to the group of mental disorders which are characterized by a sudden feeling of intense fear, panic, shortness of breath, chest pain, insomnia, fatigue, sweating, etc (Martinez et al. 2007; Keeton et al. 2009). The disorder occurs because of hyper 
responsiveness of amygdala and limbic system connected to the prefrontal cortex in the brain (Martinez et al. 2007; Keeton et al. 2009). Anxiety is mediated in the central nervous system via GABA, norepinephrine, serotonin, dopamine or peptide receptors (Martinez et al. 2007; Keeton et al. 2009). Globally, about 450 million people are affected by various mental and neurological disorders. Also, the prevalence of both mental and neurological disorders in Nigeria is increasing rapidly. Unfortunately, only small parts of the population are getting access to proper diagnosis and treatment (Wambebe 1998; WHO 2001; Danjuma et al., 2009). Reports have shown that $70 \%$ of patients in developing countries use phytotherapy as a means of treatment. Also, about $25 \%$ of orthodox medicines used worldwide were derived from medicinal plants (Wambebe 1998; WHO 2001; Danjuma et al., 2009). For these reasons, more research on the use of medicinal plants as a source of pharmaceutical treatment has become indispensable. This review aims to assess various research studies conducted on anxiolytic and sedative properties of medicinal plants in Nigeria and to find the gaps left for further improvement and drug development.

\section{Aims of the Study}

(i). To study several journals articles available on anxiolytic and sedative activities of medicinal plants within Nigeria.

(ii). To identify new areas that require further investigation and to make several recommendations

\section{MATERIALS AND METHOD}

Study Selection: Studies carried out and made available online between 2008 and 2018 were carefully selected. Consequently, this review will portray the picture of various medicinal plants tested for anxiolytic and sedative activity in Nigeria.

Data Sources: Popular academic search engines including Google Scholar, FreeFullPdf and HotBot were used to search for relevant publications using Nigerian Plant Database, HerbMed, AGRICOLA, MedlinePlus, PubMed, ScienceDirect, Springer-Link data bases. The research generated 226 relevant articles on anxiolytics and sedative properties of medicinal plants used in Nigeria.

Inclusion Criteria: Research studies carried out on medicinal plants between 2008 and 2018 were selected. Manuscript published within Nigeria that focusing primarily on the anxiolytic and sedative activity of medicinal plants were selected.

Exclusion Criteria: The review excludes all articles published before the year 2008.Studies conducted on medicinal plants outside Nigeria were not included. The study was carried out between April and September 2018.

Data Extraction: Several publications obtained from various universities and research institutions that fulfilled the inclusion criteria were considered. Finally, 82 articles were chosen and thoroughly scrutinized for eligibility. Based on the various outcomes obtained, the result was discussed, and several recommendations made. The reference sections of each article reviewed were used to search for more relevant publications and this has been included in this study.

\section{RESULTS}

\section{Description of the Articles Included}

The number of articles included were 82 from various universities and research institutes. The plant materials studied were obtained from various locations within the six geopolitical zones in Nigerian. These include Southwest, Southeast, South, Northwest, Northeast and central parts of Nigeria. In this review, about 82 publications met the inclusion criteria between 2008 and 2018 indicating the abundance of plants with anxiolytic and sedative activity as shown in Table 1.

\section{DISCUSSION}

\section{(A). Anxiolytic Actions of Medicinal Plants}

(i). Open Field Test (OFT): This method was employed to assess both anxiolytic and sedative activity of medicinal plants' extracts or isolated compounds as well as their effects on locomotor activity in laboratory animals (Acher 1973; Prut and Belzung 2003). Rodents placed in a new environment may experience signs of anxiety such as decreased mobility, exploration, grooming and rearing with concurrent increased micturition and defecation (Acher 1973; Prut and Belzung 2003). The anxiolytic action of medicinal plants reviewed was observed as follows: increase in central square crossing in Allium ascalonicum (Akindele et al., 2012) and Citrus aurantium (Yusuf et al., 2016). Similarly, increase in frequency of rearing was noticed in Curcuma longa (Ibironke and Alemonu 2013) and Parkia biglobosa (Tijjani et al., 2014). These medicinal plants have clearly shown anxiolytic potential although other tests are necessary to confirm this activity.

(ii). Elevated Plus Maze (EPM): This method was carried out specifically to test for the anxiolytic action of medicinal plants by observing their ability to alleviate fear of an open space in rodents tested (Pellow et al., 1985; Lister, 1987). In this experiment, mice displayed signs of anxiety by entering closed arm or avoiding open arm. Anxiolytic property is indicated by an increase in the frequency of entry into open arm and duration of stay (Handley and Mithani, 1984). Among the articles reviewed, anxiolytic action was demonstrated by the increase in the frequency of entry in to the open arm as observed in Paulinia pinnata (Aliyu et al., 2014) and Telfairia occidentalis (Ajao and Akindele, 2013). In addition, the increase in the time spent in an open arm was shown by Cnidoscolous acontifolius (Adebiyi et al., 2012) and Maerua angolensis (Malami et al., 2014b).

(iii). Y Maze Test (YMT): In this test anxiolytic action was established by the increase in the frequency of entry into the open arm and was noticed in Asystesia gangetica (Adeyemi et al., 2014) and Zizyphus spina-christii (Sadiq et al., 2010). Also, increase in the time spent in an open arm was shown by Citrus aurantum (Yusuf et al., 2016) and Byrsocarpus coccineus (Akindele and Adeyemi 2010).

(iv). T Maze Test (ETM): In this experiment anxiolytic action is revealed by an increase in the frequency of entry in to the open arm as well as time spent there as shown by Vernonia amygdalina (Oloruntobi et al., 2014). 


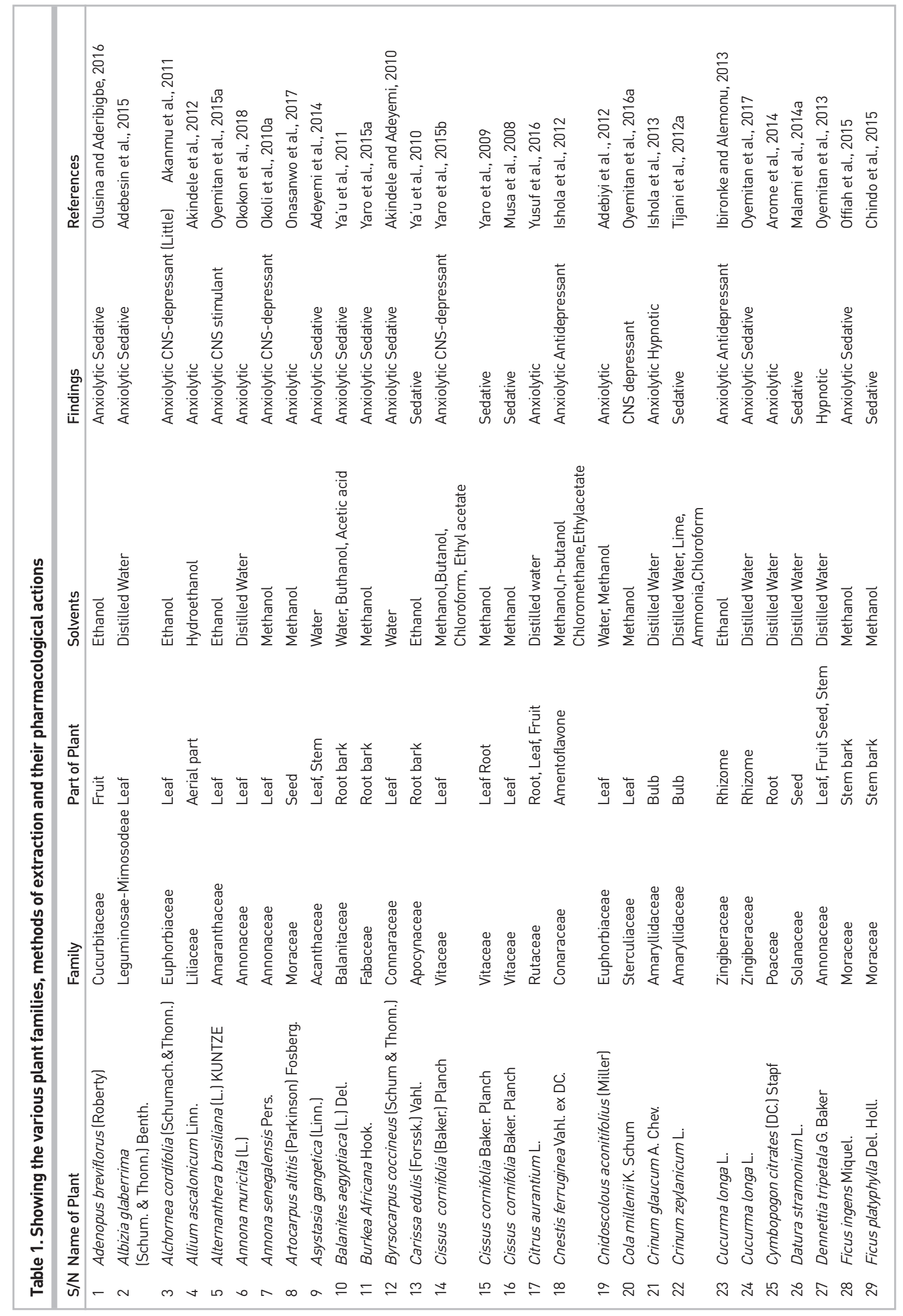




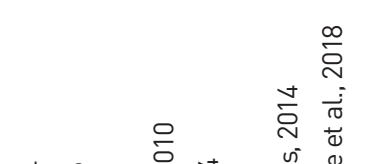

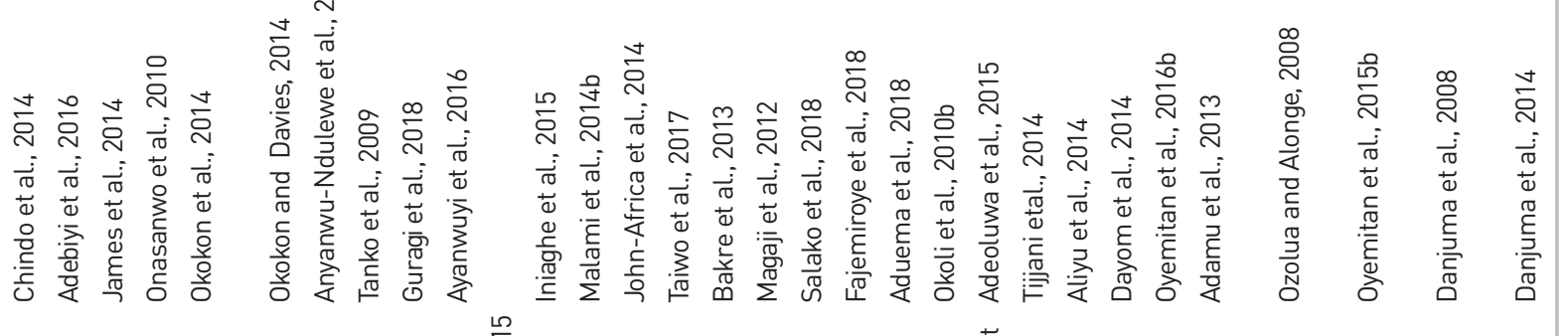

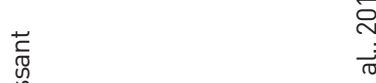
离

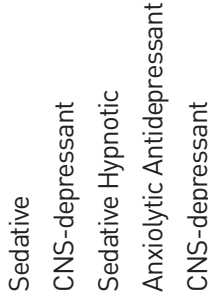
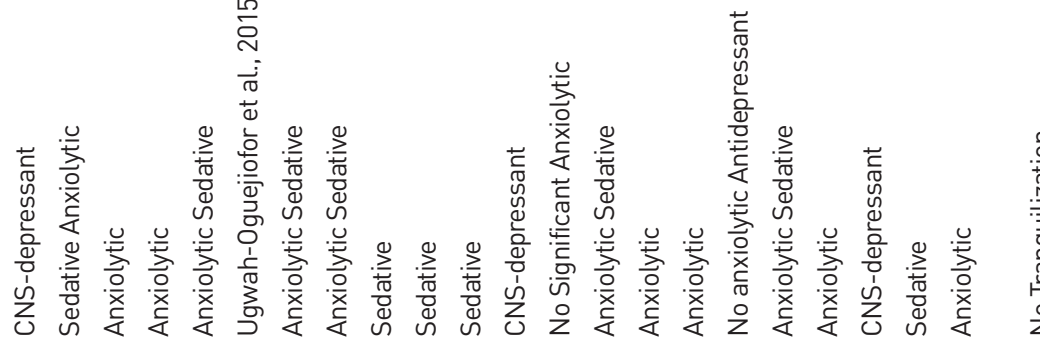

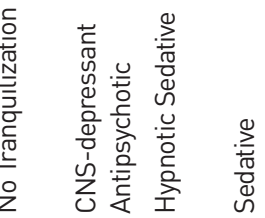

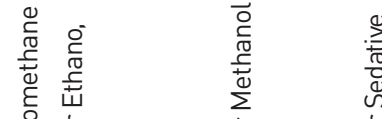

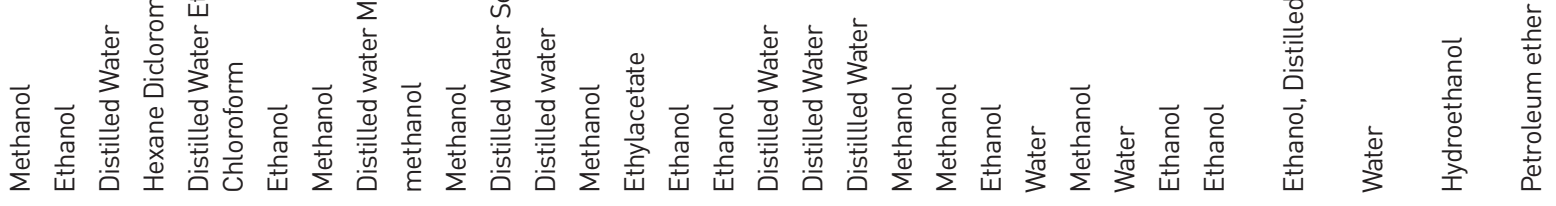

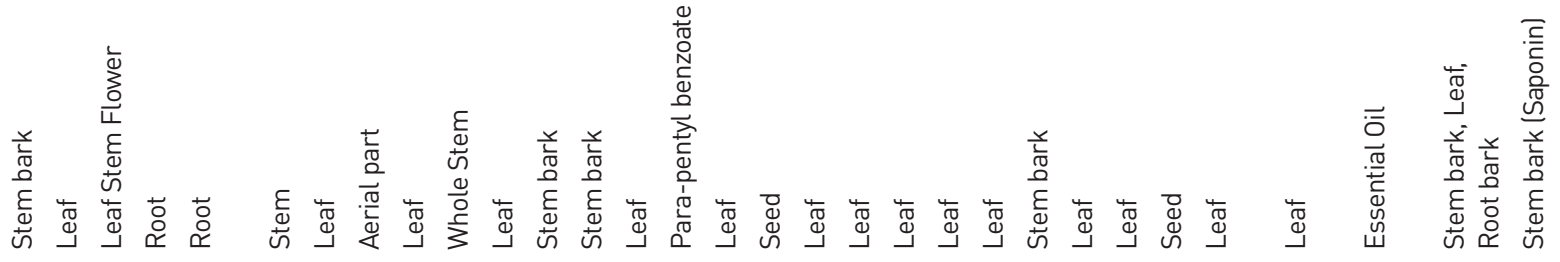

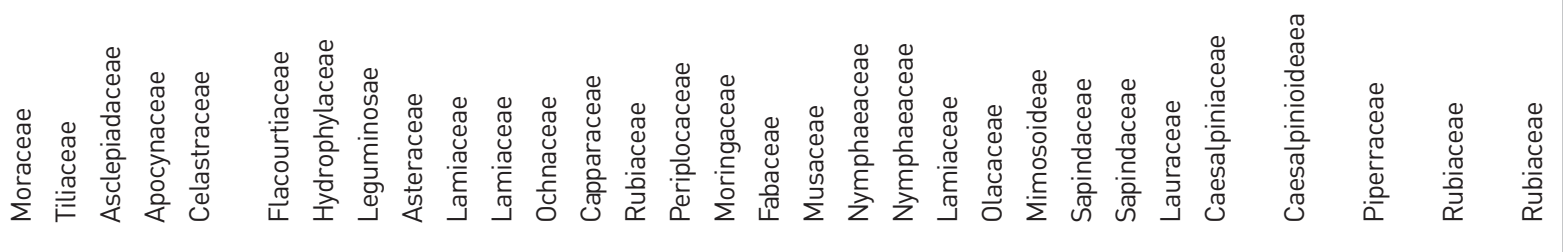

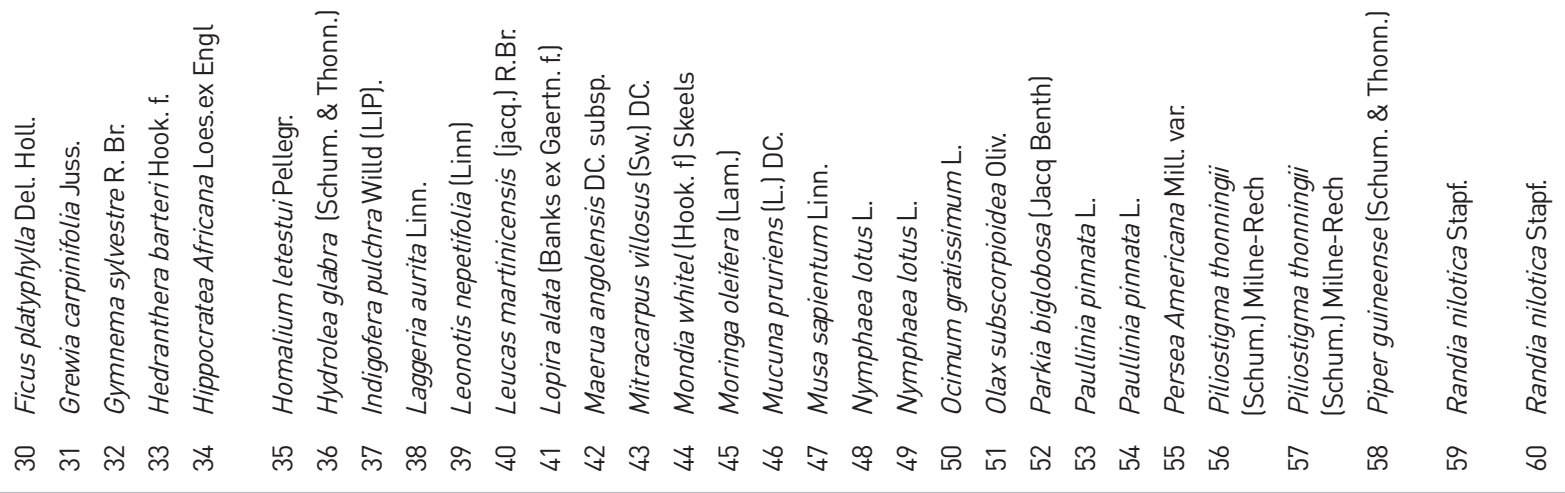




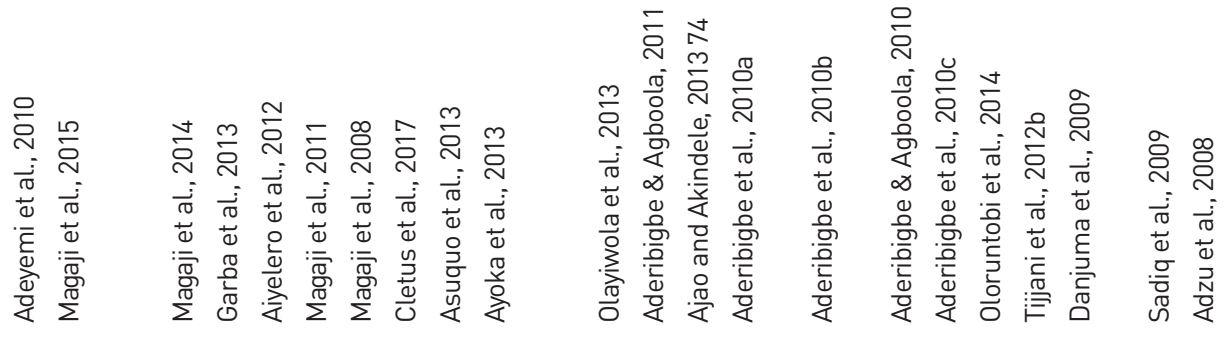

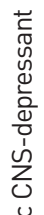

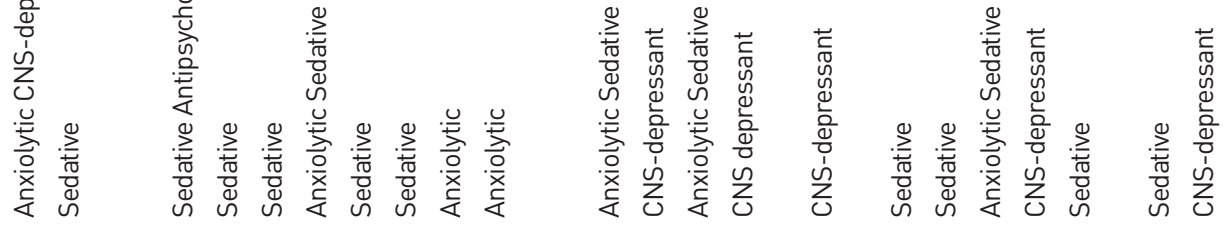

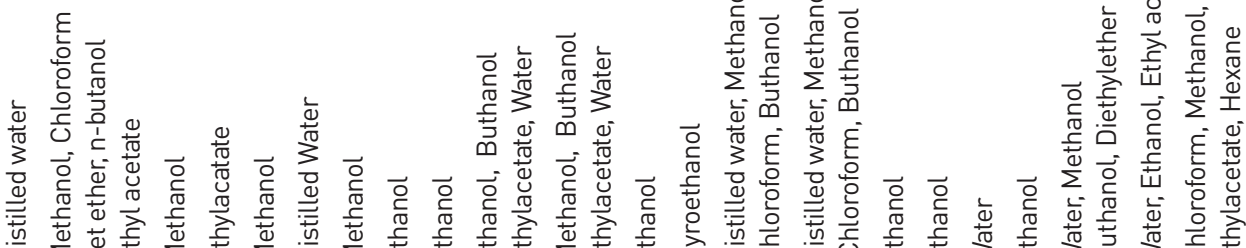

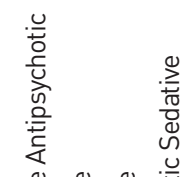

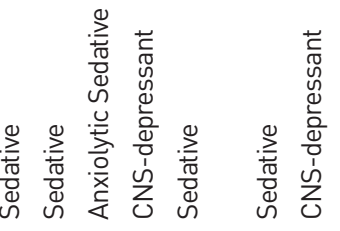

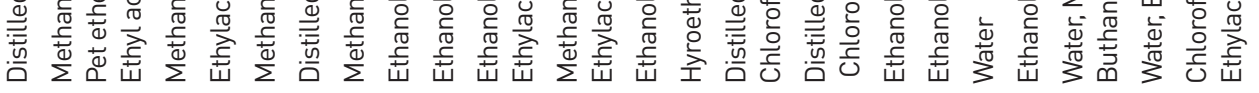

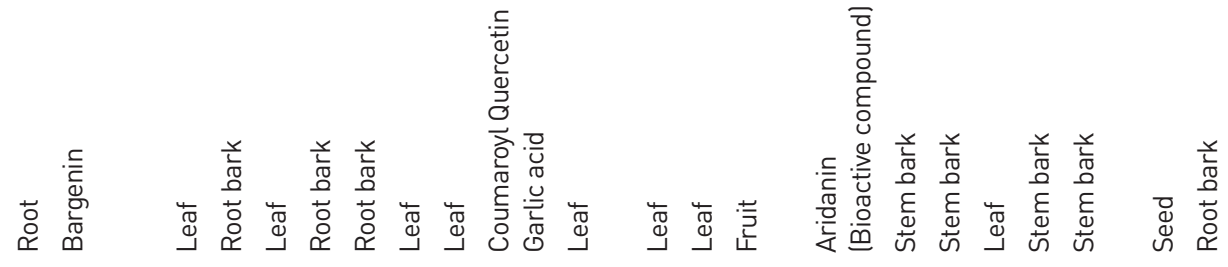
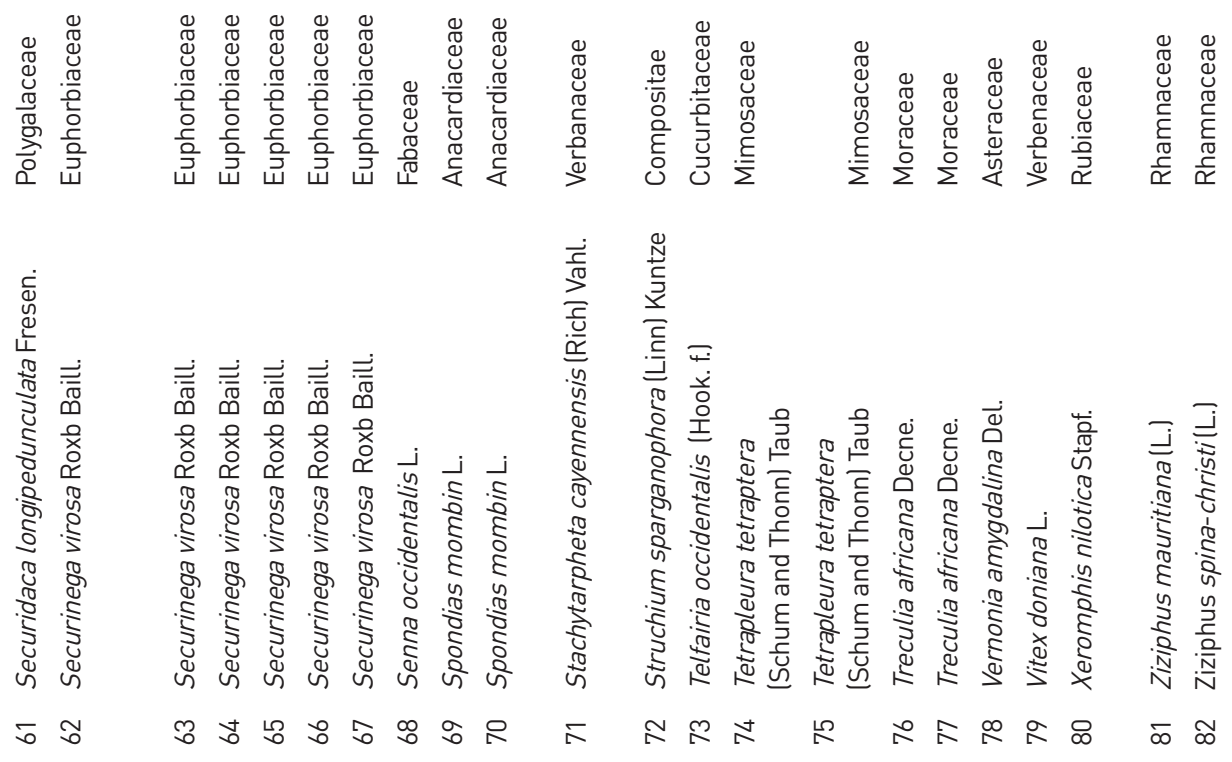
(v). Elevated Zero Maze Test (EZM): Anxiolytic action was indicated by increase in frequency of entry and time spent in an open arm as shown by Parkia biglobosa (Tijjani et al., 2014) and Citrus aurantium (Yusuf et al., 2016).

(vi). Light and Dark Exploration Test (LDE): This experiment was conducted to test for both anxiolytic and sedative action of a medicinal plant. In this test, a rodent is considered highly anxious if it spends less time in the lit compartment and more time in the dark compartment (Belzung et al., 1987). Increased time spent in the lit compartment is an indication of anxiolytic action. (Belzung et al., 1987). The parameters tested were latency in entry to the dark box and time spent in the dark box. Increase in the latency of entry into the dark box was noticed in Allium ascalonicum (Akindele et al., 2012) and Tefairia occidentalis (Ajao and Akindele 2013). Likewise, Cnestis ferruginea (Ishola et al., 2012) shows a decrease in the time spent in the dark box which revealed anxiolytic action.

(vii). Stress Induced Hyperthermia Test (SIH): Decrease in body temperature was observed following the administration of Cymbopogon citratus (Arome et al., 2014) and Struchium sparganophora (Aderibigbe and Agboola 2011) which is an indication of antianxiety activity.

(viii). Staircase Method Test (SMT): Parameters tested were frequency of rearing and number of upward steps climbed by the laboratory animals under study. Decrease in frequency of rearing indicates antianxiety while decrease in number of upward steps climbed implies CNS-depression (Simiand et al., 1984). Anxiolytic action is shown as decrease in rearing by Securinega virosa (Magaji et al., 2011) and Ficus ingens (Offiah et al., 2015). In addition, decrease in the number of upward steps climbed was observed following the administration of extract of Balanites aegyptiaca (Ya'u et al., 2011) and Paulinia pinnata (Aliyu et al., 2014) indicating sedative property.

(ix). Social Interaction Test (SIT): An increase in social activities such as grooming, sniffing, or following their partner by the laboratory animal without simultaneous rise in motor activity is an indication of anxiolytic action (File and Seth, 2003). Spontaneous increase in grooming, sniffing as well as following the partner was observed in Allium ascalonicum (Akindele et al., 2012) and Telfairia occidentalis (Ajao and Akindele, 2013) which revealed antianxiety potentials of the above medicinal plants.

(x). Hole-Board Test (HBT): In this test, an increase in head dipping by the experimental animal following the administration of a plant extract is an indication of anxiolytic action (Takeda et al., 1998) whereas decrease in head dipping signifies sedative action (File and Wardil, 1975; File and Pellow, 1985). The anxiolytic activity, which is an increase in the number of head dips by the experimental animals, was demonstrated by Allium ascalonicum (Akindele et al., 2012) and Curcuma longa (Oyemitan et al., 2017). Furthermore, the sedative action of a medicinal plant extract was shown by a decrease in the number of head dips by Adenopus breviflorus (Olusina and Aderibigbe, 2016) and Persea americana (Oyemitan et al., 2016b).

\section{(B). Sedative Action of Medicinal Plants}

(i). Open Field Test: In this test medicinal plants such as Grewia carpinifolia (Adebiyi et al., 2016) and Hippocratea africana (Okokon et al., 2014) showed sedative activity as indicated by the decrease in the number of squares crossed. Also, reduction in the frequency of rearing was noticed in Securinega virosa (Magaji et al., 2011) and Spondias mombin (Asuquo et al., 2013) indicating anxiolytic property.

(ii). Novelty Induced Behavior (NIB): This test was done to assess the CNS-depressant action of a medicinal plant. After injecting the plant extract, the parameters measured were the number of squares crossed with both limbs (locomotion), number of times the animal raised its pawns on air or placed them on a cage wall (rearing) and number of head dips (Takeda et al., 1998). Significant decrease in rearing was observed in Persea americana (Oyemitan et al., 2016b) and Piper guineense (Oyemitan et al., 2015b). Correspondingly, a decrease in locomotor activity was observed in Spondias mombin (Ayoka et al., 2013) and Stachytarpheta cayennensis (Olayiwola et al., 2013) signifying sedative activity.

(iii). Beam Walking Assay (BWA): This is another behavioral study carried out to induce minimal form of anxiety in a rodent. In this experiment, decrease in motor coordination after the administration of a plant extract suggests sedative property (Stanley et al., 2005). The parameters evaluated were the time taken to reach the goal box and the number of foot slips involving one or both hind limbs. A significant increase in the number of foot slips was noticed in Cissus cornifolia (Yaro et al., 2015b) demonstrating CNS-depressant.

(iv). Phenobarbitone Induced Sleeping Time (PIST): This test was conducted to assess the sedative nature of medicinal plants. The primary focus was onset of sleep which is loss of righting reflex. That is when mice were rolled sideways and could not stand upright using all four limbs (Miya et al., 1973). The first parameter was decrease in latency of sleep as shown by Crinum zeylanicum (Tijani et al., 2012a) and Gymnema sylvestre (James et al., 2014). The second parameter assessed was increase in the duration of sleep as seen in Hippocratea Africana (Okokon et al., 2014) and Homalium letestui (Okokon and Davies, 2014) all indicating sedative activity.

(v). Pentobarbitone Induced Sleeping Time: In this experiment Zizyphus spina-christii (John-Africa et al., 2014) significantly reduced the onset of pentobarbitone induced sleep while Mondia whitel (Taiwo et al., 2017) significantly increased the total sleeping time showing CNS depression. Potentiation of phenobarbitone and pentobarbitone sleeping time was believed to take place via augmentation of chloride ion linked GABA receptor inhibition (Tijani et al., 2012a; Dhawan et al., 2004). However, the tests described above only suggested the possibility of sedative activity of medicinal plants. This is because some medicinal plants only inhibit phenobarbitone metabolism via inhibition of cytochrome P450, prolonging its activity giving a false impression of CNS depression (Gobubkova et al., 1998).

(vi). Diazepam Induced Sleeping Time: This is another test for sedative activity of a medicinal plant. It involves evaluation 


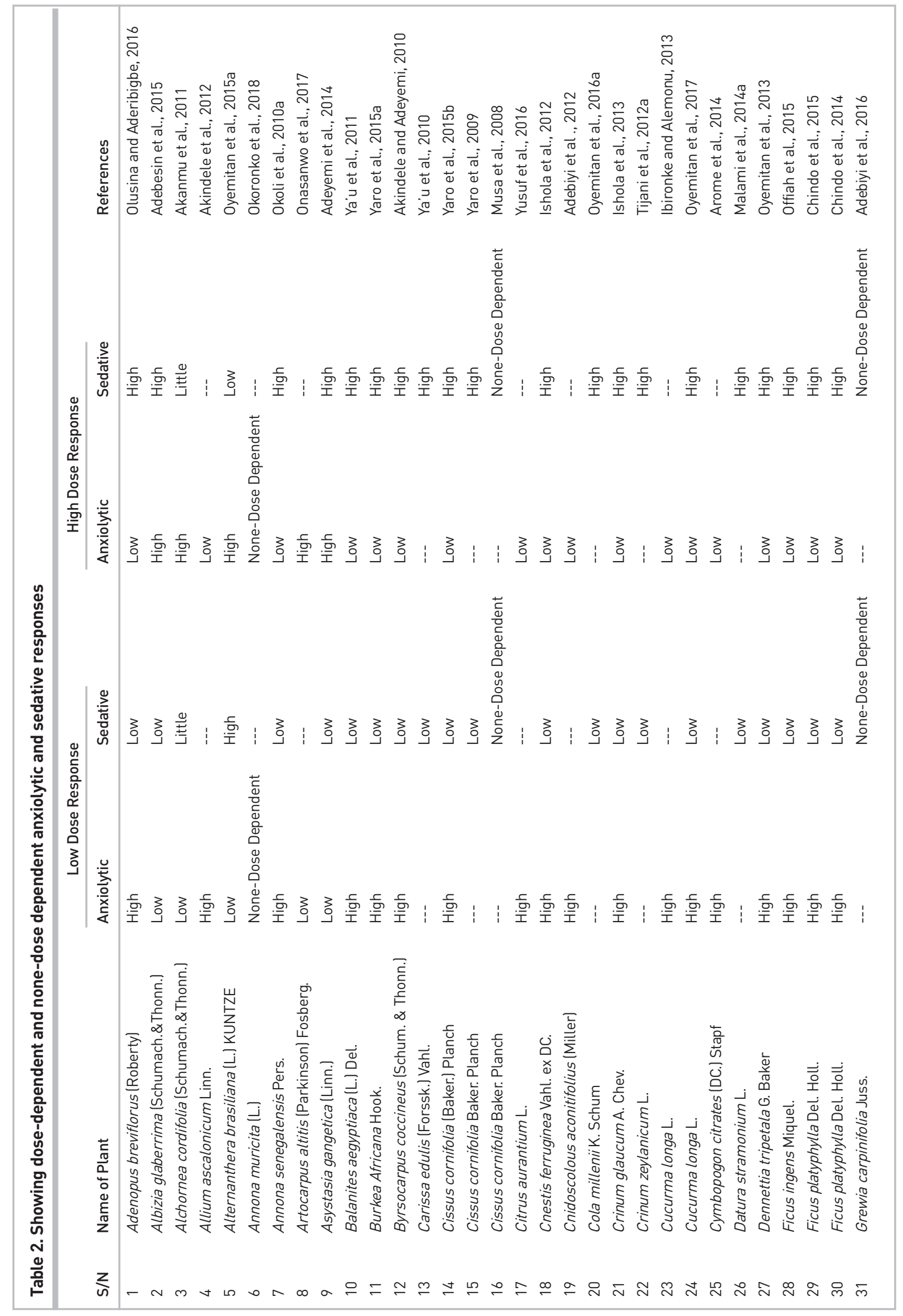




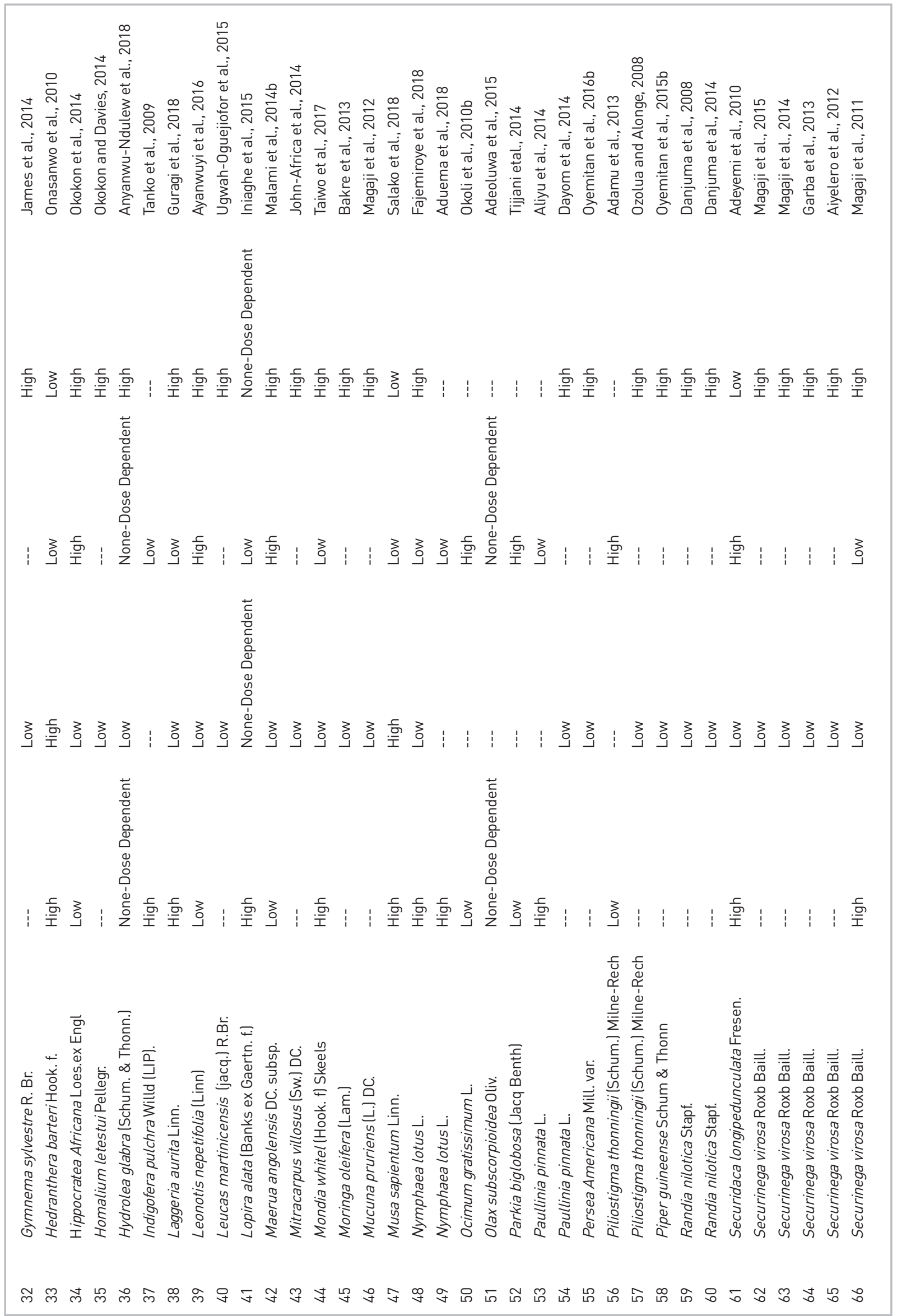




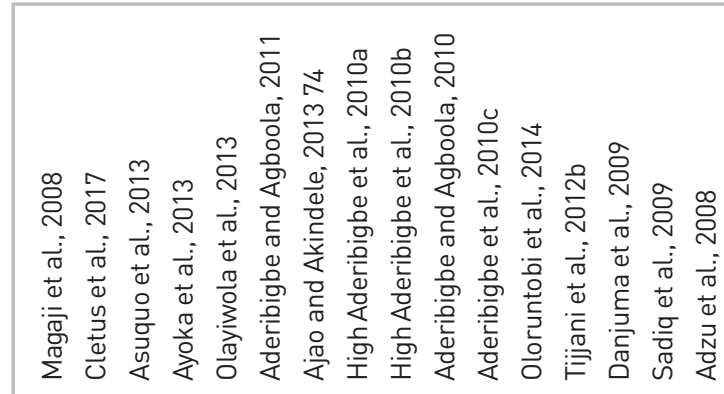

弄兽:
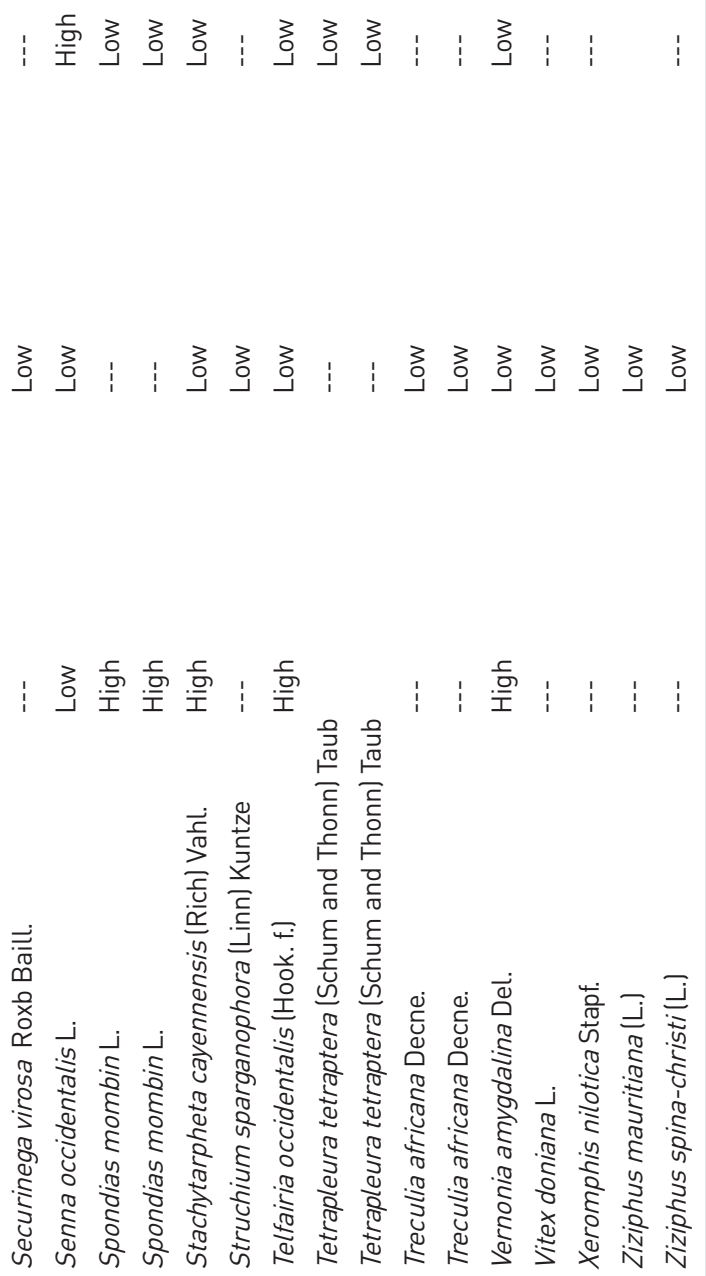

เ์ of loss of righting reflex (Miya et al., 1973). Significant decrease in the onset of sleep was observed in Balanites aegyptiaca (Ya'u et al., 2011) and Cissus cornifolia (Yaro et al., 2015b) which is an indication of sedative property. In addition, Datura stramonium (Malami et al., 2014a) and Denettia tripetala (Oyemitan et al., 2013) demonstrated an increased duration of sleep.

(vii). Ketamine Induced Hypnosis: Mice were used to test for the CNS-depressant property of medicinal plants. Studies involving Securinega virosa (Magaji et al., 2014) and Piper guineense (Oyemitan et al., 2015b) showed an increase in the duration of ketamine-induced sleeping time.

\section{(C). Other Behavioral studies}

(i). Apormorphine Induced Streotypy (AIS): This experiment was carried out to evaluate the CNS-depressant action of a medicinal plant. The parameters assessed were climbing behavior and frequency of rearing (Moore and Axton, 1998). The apormorphine induced streotypy was measured and scored as follows: $0=A b s e n c e$ of Stereotypy; $1=0$ Occasional Sniffing; 2=Occasional Gnawing; 3=Frequent Gnawing; 4=Continuous Gnawing; 5=Gnawing Intensively and Staying on the Same Spot (Okoli et al., 2010a). A significant decrease in climbing scores was observed in Ficus platyphylla (Chindo et al., 2015) and Securinega virosa (Magaji et al., 2014). Likewise, a significance decrease in frequency of rearing was observed in Piper guineense (Oyemitan et al., 2015b) indicating sedative property. The plant extract or isolated bioactive compounds were believed to reverse the apomorphine induced hyperactivity via central blockade of $\mathrm{D}_{2}$ dopaminergic receptor leading to CNS depression (Stolk and Rech, 1970). Other tests that give similar outcomes include Dexamphetamine Induced Stereotypy in which an increase in climbing score was shown by Piliostigma thonningii (Ozolua and Alonge, 2008).

(ii). Rotarod Performance Test: This method was used to assess the CNS-depressant action as well as muscle relaxant action of a medicinal plant. The experiment evaluates the duration of stay on a rotarod and loss of motor coordination by the laboratory animal (Dunhan and Miya, 1957). Notably, the decrease in the time spent on a rotarod as well as decrease in fatigue resistance is possibly due to blockade $D_{\mathbf{2}}$ dopaminergic receptor (Stolk and Rech, 1970). Furthermore, a significant decrease in motor coordination was apparent in Annona senegalensis (Okoli et al., 2010a) and Hedranthera barteri (Onasanwo et al., 2010). Similarly, a significant decrease in fatigue resistance was observed in Ficus platyphylla (Chindo et al., 2014) and Piper guineense (Oyemital et al., 2015a) indicating CNS-depression.

\section{(D). Dose-Dependence Response}

Generally, a medicinal plant may show anxiolytic property at a lower dose and at the same time may demonstrate sedative ability when given at much higher doses (Treit et al., 1984). The majority of the articles reviewed showed a dose-dependent anxiolytic or sedative response. This implies that the plant extract of most plants revealed high anxiolytic activity at a lower dose and low anxiolytic activity at a higher dose. Correspondingly, the extracts showed low sedative property at a lower dose and high sedative property at a higher dose. This is shown in Table 2. However, only a few medicinal plant extracts deviate 
from this analogy. As such, low anxiolytic activity was seen at a lower dose and high anxiolytic activity at a higher dose by Albizia glaberrima (Adebesin et al., 2015), Alchornea cordifolia (Akanmu et al., 2011), Alternanthera brasiliana (Oyemitan et al., 2015a), Artocarpus altitis (Onasanwo et al., 2017), Asystesia gangetica (Adeyemi et al., 2014), Cissus cornifolia (Yaro et al., 2015b), Hippocratea africana (Okokon et al., 2014), Leonotis nepetifolia (Ayanwuyi et al., 2016), Maerua angolensis (Malami et al., 2014b), Ocimum gratissimum (Okoli et al., 2010b), Parkia biglobosa (Tijjani et al., 2014), Piliostigma thonningii (Adamu et al., 2013), and Senna occidentalis (Cleatus et al., 2017). Similarly, high sedative property was seen at a lower dose with low sedative property at a higher dose by Hedranthera barteri (Onasanwo et al., 2010) and Musa sapientum (Salako et al., 2018).

\section{CONCLUSION}

Several research studies using laboratory animals were reviewed which tested the reported claims of anxiolytic or sedative activities of medicinal plants. About 82 different medicinal plants were tested between 2008 and 2018 indicating an abundance of plants with anxiolytic and sedative activity in Nigeria. The plants on which experiments were conducted showed dose-dependent anxiolytic and sedative activity with better anxiolytic response at lower doses and greater sedative at higher doses. Nonetheless, findings from this review suggested that there are still several medicinal plants with anxiolytic and or sedative activities claims in Nigeria yet to be scientifically tested. Techniques such as Open Field Test, Elevated Plus Maze, Y Maze Test, T Maze Test, Elevated Zero Maze Test, Light and Dark Exploration Test, Stress Induced Hyperthermia Test, Staircase Method Test, Social Interaction Test, and Hole-Board Test were commonly employed in testing the anxiolytic property of medicinal plants in Nigeria. In addition, Open Field Test, Novelty Induced Behavior, Beam Walking Assay, Phenobarbitone Induced Sleeping Time, Pentobarbitone Induced Sleeping Time, Diazepam Induced Sleeping Time, and Ketamine Induced Hypnosis methods were frequently used in testing the sedative activity of medicinal plants. Furthermore, other studies commonly employed in behavioral studies include Apormorphine Induced Streotypy and Rotarod Performance Test. Consequently, this has led to advancements made in the field of psychopharmacology in Nigeria. In order to obtain target specific activities of these medicinal plants, the bioactive molecules that are responsible for the identified pharmacological activity should be figure out and isolated. Also, due to the abundance of medicinal plants among the Nigerian flora with various claims in folklore medicine, delving into the advanced ethno medicinal research will yield several phytomedicines that could be used in the treatment of anxiety in Nigeria.

Peer-review: Externally peer-reviewed.

Author Contributions: Concept - A.R.A., M.H.; Design - A.R.A., M.H.; Supervision - A.R.A., M.H.; Resource - A.R.A., M.H.; Materials - A.R.A., M.H.; Data Collection and/or Processing - A.R.A., M.H.; Analysis and/or Interpretation - A.R.A., M.H.; Literature Search - A.R.A., M.H.; Writing A.R.A., M.H.; Critical Reviews - A.R.A., M.H.
Acknowledgements: I wish to extend a special gratitude to all the staff of the department of pharmacology, faculty of pharmaceutical Sciences, Bayero University, Kano, Nigeria.

Conflict of Interest: The authors have no conflict of interest to declare.

Financial Disclosure: The authors declared that this study has received no financial support.

\section{REFERENCES}

- $\quad$ Adamu MA, Yahaya TA, Abigail B, Adeola SO (2013). Pharmacological effects of Piliostigma thonningii leaf extract on anxiety-like behaviour and spatial memory in Wistar albino rats. Phytopharmacology 4: 561-568.

- $\quad$ Adebesin IF, Akindele AJ, Adeyemi OO. (2015). Evaluation of neuropharmacological effects of aqueous leaf extract of Albizia glaberrima (Leguminosae) in mice. J Ethnopharmacol 160: 101-108. [CrossRef]

- $\quad$ Adebiyi OA, Adebiyi OO, llesanmi OR, AduT (2012). Anxiolytic and anti-nociceptive activity of hydroalcholic leaf extract of Cnidoscolous acontifolius. Afr Pharm Pharmacol 6: 1765-1769. [CrossRef] Adebiyi OE, Olopade FE, Olopade JO, Olayemi FO (2016). Behavioural studies on the ethanol leaf extract of Grewia carpinifolia in Wistar rats. Afr Health Sci 16: 339-346. [CrossRef]

- Adeoluwa OA, Aderibigbe AO, Bakre AG (2015). Evaluation of Antidepressant-like Effect of Olax Subscorpioidea Oliv. (Olacaceae) Extract in Mice. Drug Res 65: 306-311. [CrossRef]

- Aderibigbe A, Agboola O (2010). Studies of behavioural and analgesic properties of Treculia africana in mice. Int J Biol Chem Sci 4 338-346. [CrossRef]

- $\quad$ Aderibigbe AO, Agboola Ol (2011). Neuropharmacological profile of Struchium sparganophora (Linn) O. Ktze in mice. Asian J Tradit Med 6: 104-111.

- Aderibigbe OA, Iwalewa OE, Adesina KS, Agboola IO (2010a). Anxiolytic effect of aridanin isolated from Tetrapleura tetraptera in mice. Int J Biol Chem Sci 4: 1390-1396. [CrossRef]

- $\quad$ Aderibigbe OA, Iwalewa OE, Adesina KS, Agboola IO (2010b). Studies of behavioural and neural mechanism of Aridanin isolated from Tetrapleura tetraptera in mice. Int J Pharmacol 6: 480-486. [CrossRef]

- $\quad$ Aderibigbe AO, Adeyemi IO, Agboola Ol (2010c). Central nervous system depressant properties of Treculia africana Decne. Ethnobotanical Leaflets 2010: 14:108.

- $\quad$ Adeyemi OO (2014). Investigation of the Anticonvulsant, Sedative and Anxiolytic Activities of the Aqueous Leaf and Stem Extract of Asystasia gangetica (Linn.). UNILAG J Basic Med Sci 2: 19-26.

- $\quad$ Adeyemi OO, Akindele AJ, Yemitan OK, Aigbe FR, Fagbo FI (2010). Anticonvulsant, anxiolytic and sedative activities of the aqueous root extract of Securidaca longipedunculata Fresen. J Ethnopharmacol 130: 191-195. [CrossRef]

- $\quad$ Aduema W, Akunneh-Wariso C, Amah AK, Vidona WB (2018). Evaluation of the anxiolytic activity of the leaves of Nymphaea lotus (Water Lily) in mice. Biol Med Case Rep 2: 21-24.

- $\quad$ Adzu B, Haruna AK, llyas M, Gamaniel KS (2008). CNS activity of ZS-1A: a phytoceutical from Zizyphus spina-christi root bark. IJBCS 2: 456-461. [CrossRef]

- $\quad$ Aiyelero OM, Abdu-Aguye SN, Yaro AH, Magaji MG (2012). Behavioural studies on the methanol leaf extract of Securinega virosa (Euphorbiaceae) in mice. J Pharmacognosy Phytother 4: 12-15. [CrossRef]

- $\quad$ Ajao MY, Akindele AJ (2013). Anxiolytic and sedative properties of hydroethanolic extract of Telfairia occidentalis leaves in mice. Rev Bras Farmacogn 23: 301-309. [CrossRef]

- Akanmu MA, Adeloye AO, Obuotor EM, Adelusola KA, Iwalewa EO, Ukponmwan OE, Lamikanra A (2011). Neuropharmacological effects of Alchornea cordifolia (Schumach. \& Thonn.) Mull. Arg.(Euphorbiaceae) in mice. Int J Biol Chem Sci 5: 2250-2262. [CrossRef] 
- $\quad$ Akindele AJ, Adeyemi OO (2010). Anxiolytic and sedative effects of Byrsocarpus coccineus Schum. and Thonn. (Connaraceae) extract. Int J Appl Res Nat Prod 3: 28-36.

- $\quad$ Akindele AJ, Sanni HA, Edeh PC (2012). Anxiolytic activity of aerial part hydroethanolic extract of Allium ascalonicum Linn. (Liliaceae) in mice. FFHD 2: 448-459. [CrossRef]

- Aliyu M, Anuka JA, Yaro AH, Magaji MG (2014). Evaluation of the Anxiolytic Effect of Methanolic Leaves Extract of Paullinia pinnata Lin in Mice. Br J Pharm Res 4: 1638. [CrossRef]

- Anyanwu-Ndulewe CA, Adepoju-Bello AA, Fageyinbo S, Coker H (2018). Extract of the Leaves of Hydrolea glabra Schum. \&Thonn. (Hydrophyllaceae), Exerts Anxiolytic Effect on Swiss Albino Mice. Trop J Nat Prod Res 2: 413-417 [CrossRef]

- $\quad$ Archer J (1973). Tests for emotionality in mices and mice, a review. Anim Behav 21: 205-235. [CrossRef]

- Arome D, Enegide C, Ameh SF (2014). Pharmacological evaluation of anxiolytic property of aqueous root extract of Cymbopogon citratus in mice. Chron Young Sci 5: 33-38. [CrossRef]

- $\quad$ Asuquo OR, Ottoh MO, Eluwa MA, Oko OK, Ekanem TB (2013). Locomotor Activity of Ethanolic Extract of Spondias Mombin Leaf. Int J Pharm Sci Invent 2: 2131-6178.

- $\quad$ Ayanwuyi LO, Kwanashie HO, Hussaini IM, Yaro AH (2016). Preliminary studies on the behavioural effects of the methanol extract of Leonotis nepetifolia Linn stem in mice. Afr J Trad Compl Altern Med 13: 15-21. [CrossRef]

- Ayoka AO, Owolabi RA, Bamitale SK, Akomolafe RO, Aladesanmi JA, Ukponmwan EO (2013). Effect of fractionated extracts and isolated pure compounds of spondias mombin (L. Anacardiaceae) leaves on novelty-induced rearing and grooming behaviors in mice. Afr J Tradit Complement Altern Med 10: 244-255. [CrossRef]

- Bakre AG, Aderibigbe AO, Ademowo OG. (2013). Studies on neuropharmacological profile of ethanol extract of Moringa oleifera leaves in mice. J Ethnopharmaco/ 149: 783-789. [CrossRef]

- Belzung C, Misslin R, Vogel E, Dodd RH, Chapouthier G (1987). Anxiogenic effects of methyl- $\beta$-carboline-3-carboxylate in a light/dark choice situation. Pharmacol Biochem Behavior 28: 2933. [CrossRef]

- Chindo BA, Jamilu YU, Danjuma NM, Okhale SE, Gamaniel KS, Becker A (2014). Behavioral and anticonvulsant effects of the standardized extract of Ficus platyphylla stem bark. J Ethnopharmaco/ 154: 351-360. [CrossRef]

- Chindo BA, Kahl E, Trzeczak D, Dehmel P, Becker A, Fendt M (2015). Standardized extract of Ficus platyphylla reverses apomorphine-induced changes in prepulse inhibition and locomotor activity in rats. Beh Brain Res 293: 74-80. [CrossRef]

- Cletus AU, Dibal MY, Malgwi TS, Hadiza MI, Adama YA (2017). Central Nervous System Depressant Effect of Senna occidentalis Linn. (Fabaceae) Leaf Extract in Mice. Br J Pharm Res 18: 1-6. [CrossRef]

- Danjuma NM, Abdu-Aguye I, Anuka JA, Hussaini IM, Zezi AU, Maiha BB, Sani M (2008). Behavioural Effects of Hydroalcoholic Stem Bark Extract of Randia nilotica stapf, in Mice. Int J Pharmacol 4 264-269. [CrossRef]

- Danjuma NM, Zezi AU, Yaro AH, Musa AM, Ahmed A, Sanni HA, Maje IM (2009). Residual aqueous fraction of stem bark extract of Xeromphis nilotica and behavioral effects in mice. Int J Appl Res NatProd 2: 5-12.

- Danjuma NM, Chindo BA, Abdu-Aguye I, Anuka JA, \& Hussaini IM. (2014). Psychopharmacological properties of saponins from Randia nilotica stem bark. Pharmaceutical Biology 52: 1-7. [CrossRef]

- Dayom DW, Gyang SS, Jimam SN, Okwuasaba FK (2014). Effects of Aqueous Leaf Extract of Paulinia Pinnata on Swimming Endurance Time of Mice. J Pharm Biol Sci 9: 47-50. [CrossRef]

- Dhawan K, Dhawan S, Sharma A (2004). Passiflora: a review update. J Ethnopharmaco/ 94: 1-23. [CrossRef]
Dunhan NW, Miya TS (1957). A note on a simple apparatus for detecting neurological deficit in rats and mice. J Am Pharm Assoc 46: 208-209. [CrossRef]

Edewor-Kuponiyi TI (2013). Plant-derived compounds with potential sedative and anxiolytic activities. Int J Basic Appl Sci 2: 63-78.

Egharevba HO, Ibrahim JA, Kassam CD, Kunle OF (2015). Integrating traditional medicine practice into the formal health care delivery system in the new millennium-the Nigerian approach: a review. Int J Life Sci 4: 120-128.

Fajemiroye JO, Zjawiony Jordan K, Alves CE, Aderoju AA (2018). Evaluation of Anxiolytic and Antidepressant-like Activity of Aqueous Leaf Extract of Nymphaea Lotus Linn. in Mice. Iran J Pharm Res 17: 613-626.

File S, Pellow S (1985). The effect of Triazolobenzodiazepines in two animal tests of anxiety and on Hole -board. Br J Pharmacol 86: 729-735. [CrossRef]

File SE, Seth P (2003). A review of 25 years of the social interaction test. Eur J Pharmaco/ 463: 35-53. [CrossRef]

Files S, Wardill AG (1975). Validity of head-dipping as a measure of exploration a modified hole -board. Psychopharmacology (Berl) 44: 5-9. [CrossRef]

Garba MM, Hamza YA, Muhammad MA, Akpojo AJ, Ibrahim AA, Marte HI (2013). Neuropharmacological studies on ethyl acetate fraction of Securinega virosa root bark extract. Afr J Pharm Pharmacol 7: 275-279. [CrossRef]

Goloubkova TD, Heckler E, Rates SMK, Henriques JAP, Henriques AT (1998). Inhibition of cytochrome P450-dependent monooxygenases by an alkaloid fraction from Helietta apiculata markedly potentiate the hypnotic action of pentobarbital. J Ethnopharmacol 60: 141-148. [CrossRef]

Guragi IA, Kyari H, Malami S (2018). Anxiolytic-Like Effect of Methanol Leaf Extract of Laggera aurita Linn. F.(Asteraceae) in Mice. Arch Neuro Sci 5: e63441. [CrossRef]

Handley SL, Mithani S (1984). Effects of alpha-adrenoceptor agonists and antagonists in a maze-exploration model of 'fear'-motivated behaviour. Naunyn Schmiedebergs Arch Pharmaco/ 372: 1-5. [CrossRef]

Ibironke GF, Alemonu OJ (2013). Effects of Ethanol Extract of Curcuma Longa Rhizome on Neurobehavioural Activities in Stressed Rats. Afr J Biomed Res 16: 193-197.

- $\quad$ Iniaghe LO, Ighodaro I, Magaji MG, Tabot TP, Maduka IT. (2015). Neurobehavioural evaluation of Lophira alata (Ochnaceae) stem bark extract in mice.J Basic Clin Physiol Pharmaco/ 26: 523-529. [CrossRef] Ishola IO, Chatterjee M, Tota S, Tadigopulla N, Adeyemi OO, Palit G, Shukla R (2012). Antidepressant and anxiolytic effects of amentoflavone isolated from Cnestis ferruginea in mice. Pharmacol Biochem Behav 103: 322-331. [CrossRef]

Ishola IO, Olayemi SO, Idowu AR (2013). Anticonvulsant, anxiolytic and hypnotic effects of aqueous bulb extract of Crinum glaucum A. chev (Amaryllidaceae): role of GABAergic and nitrergic systems. PakJ Biol Sci 16: 701-710. [CrossRef]

- James O, Awam MN, Eleojo O (2014). Hypno-sedative activity of Gymnema sylvestre extract in sodium barbiturate - induced hypnosis in Rattus novergicus. Adv Biochem 2: 60-64. [CrossRef]

John-Africa LB, Danjuma NM, Anuka JA, Chindo BA (2014). Sedative properties of Mitracarpus villosus leaves in mice. IJBCS 8 : 2132-2142. [CrossRef]

Keeton CP, Kolos AC, Walkup JT (2009). Pediatric Generalized Anxiety Disorder Epidemiology, Diagnosis, and Management. Pediatric Drugs 11: 171-183. [CrossRef]

- Lister RG (1987). The use of a plus-maze to measure anxiety in the mouse. Psychopharmacology (Berl) 92: 180-185. [CrossRef] Magaji MG, Anuka JA, Abdu-Aguye I, Yaro AH, Hussaini IM (2008). Behavioural Effects of the methanolic root bark extract of Secu- 
rinega virosa in rodents. Afr J Tradit Complement Altern Med 5: 147153. [CrossRef]

- Magaji MG, Musa AM, Abdullahi MI, Ya’u J, Hussaini IM (2015). Isolation of bergenin from the root bark of Securinega virosa and evaluation of its potential sleep promoting effect. Avicenna J of Phytomed 5: 587-596.

- Magaji MG, Yakubu Y, Magaji RA, Musa AM, Yaro AH, Hussaini IM (2014). Psychopharmacological potentials of Methanol leaf extract of Securinega virosa Roxb (Ex Willd) Baill. in mice. Pak J Biol Sci 17: 855-859. [CrossRef]

- Magaji MG, Yaro AH, Musa AM, Anuka JA, Abdu-Aguye I, Hussaini IM (2011). Sedative activity of residual aqueous fraction of Securinega virosa (Roxb. ex Willd) Baill. Root bark extract in mice. Niger J Pharm Sci 10: 34-44.

- Magaji RA, Saleh MIA, Magaji MG, Buhari I (2012). Preliminary Central Nervous System Effects of the Aqueous Seed Extract of Mucuna pruriens in Mice. Current Research in Neuroscience 4: 6-9. [CrossRef]

- Malami I, Halilu ME, Mathias S, Alhassan MA (2014a). Phytochemical evaluation and investigations in to sedative properties of Datura stramonium (Linn) seeds in experimental mice. J Pharm Biol Sci 9: 1-3. [CrossRef]

- Malami I, Hassan SW, Alhassan AM, Shinkafi ST, Umar AT, Shehu S (2014b). Anxiolytic, sedative and toxicological effect of hydromethanolic stem bark extract of maerua angolensis DC. In Wister rats. Pak J Pharm Sci 27: 1363-1370.

- Martinez RCR, de Oliveira AR, Brandão ML (2007). Serotonergic mechanisms in the basolateral amygdala differentially regulate the conditioned and unconditioned fear organized in the periaqueductal gray. Eur Neuropsychopharmacol 17: 717-724. [CrossRef] - Miya TS, Holck HGO, Yui GKW, Spratto GR (1973). Laboratory guide in Pharmacology. Minneapolis MN: Burgess Publishing Company.

- Moore NA, Axton MS (1988). Production of climbing behaviour in mice requires both D1 and D2 receptors activation. Psychopharmacology (Berl) 94: 261-269. [CrossRef]

- Musa AM, Yaro AH, Usman H, Magaji MG, Habu M (2008). Phytochemical and some neuropharmacological studies on the methanolic leaf extracts of Cissus cornifolia (Vitaceae) in mice. Int J Pharmaco/ 4: 145-148. [CrossRef]

- Offiah RO, Salawu OA, Anuka JA, Magaji MG, Tijani AY (2015). Behavioural studies on the methanolic stem bark extract of Ficus Ingens (Miquel) Miquel (Moraceae) in mice. Afr J Pharml Res Dev 7: 11-18.

- Okokon JE, Davies K (2014). Psychopharmacological studies of Homalium letestui stem extract. J Pharmaceut Bio/ 4: 158-164.

- Okokon JE, Davies K, Antia BS, Okokon PJ (2014). Depressant, Anticonvulsant and Antibacterial Activities of Hippocratea Africana. Int J Phytother 4: 144-153.

- $\quad$ Okoli CO, Ezike AC, Agwagah OC, Akah PA (2010b). Anticonvulsant and anxiolytic evaluation of leaf extracts of Ocimum gratissimum, a culinary herb. Pharmacognosy Res 2: 36-40. [CrossRef]

- Okoli CO, Onyeto CA, Akpa BP, Ezike AC, Akah PA, Okoye TC (2010a). Neuropharmacological evaluation of Annona senegalensis leaves. Afr J Biotechnol 9: 8435-8444.

- Okoronkwo SO, Uchewa OO, Egwu EO, Okoronkwo AC. (2018). Evaluation of the Anxiolytic Activities of Aqueous Leaf Extract of Annona Muricata and its Effect on the Microanatomy of the Cerebrum. Int J Biol Med Res 9: 6366-6370.

- Olayiwola G, Ukponmwan O, Olawode D (2013). Sedative and anxiolytic effects of the extracts of the leaves of Stachytarpheta Cayennensis in mice. Afr J Tradit Complement Altern Med 10: 568-579. [CrossRef]

- $\quad$ Oloruntobi IJ, Ajayi Ol, Rufus $1 \mathrm{O}$ (2014). Anxiolytic, Sedative and Hypothermic Effects of Aqueous Leaf Extract of Vernonia amygdalina Del.(Asteraceae) in Albino Mice. Br J Pharm Res 4: 2210. [CrossRef]
Olusina OK, Aderibigbe AO (2016). Anxiogenic Effect of Ethanol Extract of Adenopus breviflorus (Roberty) Fruit in Mice. Int $J$ Pharm SciRev Res 38: 15-19.

Onasanwo SA, Ajah AA, Aitokhuehi NG, Faborode OS (2017). Anxiolytic Potentials of Artocarpus altilis (Breadfruit) in Swiss Mice. Ann Depress Anxiety 4: 1089. [CrossRef]

Onasanwo SA, Chatterjee M, Palit G (2010). Antidepressant and anxiolytic potentials of dichloromethane fraction from Hedranthera barteri. Afr J Biomed Res 13: 76-81.

- $\quad$ Oyemitan IA, Bello OA, Akinpelu LA (2015a). Neuropharmacological Evaluation of Ethanolic Leaf Extract of Alternanthera Brasiliana (L.) Kuntze (Amaranthaceae) in Mice. Int J Pharmal Sci Res 6: 3796. Oyemitan IA, Elusiyan CA, Akanmu MA, Olugbade TA (2013). Hypnotic, anticonvulsant and anxiolytic effects of 1-nitro-2-phenylethane isolated from the essential oil of Dennettia tripetala in mice. Phytomedicine 20: 1315-1322. [CrossRef]

Oyemitan IA, Elusiyan CA, Onifade AO, Akanmu MA, Oyedeji AO, McDonald AG (2017). Neuropharmacological profile and chemical analysis of fresh rhizome essential oil of Curcuma longa (turmeric) cultivated in Southwest Nigeria. Toxicology Reports 4: 391398. [CrossRef]

Oyemitan IA, Kolawole F, Abass L, Oyedeji AO (2016a). Neuropharmacological Activities of Ethanolic Extract of Cola millenii Dried Leaf in Rats. Eur J Med Plants 16: 1-12. [CrossRef]

- Oyemitan IA, Ojo E, Oyedeji AO (2016b). Neuropharmacological profile of ethanolic dried seed extract of P ersea americana in mice. Afr J Pharm Pharmacol 10: 480-492. [CrossRef]

Oyemitan IA, Olayera OA, Alabi A, Abass LA, Elusiyan CA, Oyedeji AO, Akanmu MA (2015b). Psychoneuropharmacological activities and chemical composition of essential oil of fresh fruits of Piper guineense (Piperaceae) in mice. J Ethnopharmacol 166: 240-249. [CrossRef]

Ozolua Rl, Alonge P (2008). Aqueous and ethanol leaf-extracts of Piliostigma thonningii (Schum) increase locomotor activity in Sprague-Dawley rats. Afr J Biotechnol 7: 073-076.

- $\quad$ Pellow S, Chopin P, File SE, Briley M (1985). Validation of open: closed arm entries in an elevated plus-maze as a measure of anxiety in the rat. J Neurosci Methods 14: 149-167. [CrossRef]

- $\quad$ Prut L, Belzung C (2003). The open field as a paradigm to measure the effects of drugs on anxiety-like behaviors: a review. Eur J Pharmacol 463: 3-33. [CrossRef]

Rungsung W, Ratha KK, Dutta S, Dixit AK, Hazra J (2015). Secondary metabolites of plants in drugs discovery. WJPR 4: 604-613.

- Sadiq Y, Alexander AB, Abdulkarim A (2009). Effect of Ziziphus mauritiana (L.) seed extracts on spatial recognition memory of rats as measured by the Y-maze test. J Nat Prod 2: 31-39.

Salako OA, Akindele AJ, Balogun AO, Adeyemi OO (2018). Investigation of Antidepressant, Anxiolytic and Sedative Activities of the Aqueous Leaf Extract of Musa sapientum Linn.(Banana; Musaceae). Drug Res 3: 1-8 [CrossRef]

Simiand J, Keane PE, Moore M (1984). The staircase test in mice: a simple and effective procedure for primary screening of anxiolytic agents. Psychopharmacol (Berl) 84: 48-53. [CrossRef]

Stanley JL, Lincoln RJ, Brown TA, McDonald LM, Dawson GR, Reynolds DS (2005). The mouse beam walking assays offers improved sensitivity over the mouse rotarod in determining motor coordination deficits induced by benzodicazepines. J Psychopharmacol 19: 221-227. [CrossRef]

- Stolk JM, Rech RH (1970). Antagonism of O-amphetamine by methyl-ptyrosin. Behavioural evidence for participation of cathelcolamine stores and synthesis in the amphetamine stimulant response. Neuropharmacology 9: 249-263. [CrossRef]

Taiwo BJ, Osasan JY, Olubiyi OO, Oyemitan IA, Atoyebi SA, Elsegood MR, Jones RC (2017). Isolation of novel para-pentyl phenyl benzoate from Mondia whitei.(Hook. F.) skeels (periplocaceae), its 
structure, synthesis and neuropharmacological evaluation. Afr J Tradit Complement Altern Med 14: 219-230. [CrossRef]

- Takeda H, Tsuji M, Matsumiya T (1998). Changes in head-dipping behaviour in the hole-board test reflect the anxiogenic and/or anxiolytic state in mice. Eur J Pharmaco/ 350: 21-29. [CrossRef]

- Tanko Y, Ezekiel I, Okpanachi AO, Goji AD, Ndebi H, Musa KY, Mohammed A (2009). Behavioural Effects of Hydro-methanolic Crude Extract of Aerial Part of Indigofera pulchra in Mice. CRJBS 1: 89-93.

- Tijani AY, Salawu OA, Odeniran AO (2012a). Neuropharmacological effects of Crinum zeylanicum alkaloid fraction in laboratory animals. Pharmacol Online 1: 51-58.

- Tijjani MA, Abdurahaman Fl, Khan IZ, Sandabe UK (2012b). The Effects of Ethanolic Extract of Vitex Doniana Stem Bark on Peripheral and Central Nervous System of Laborotory Animals. J Appl Pharm Sci 2: 74-79.

- Tijjani YA, Okhale SE, Adeola SO (2014). Neuropharmacological effects of standardized aqueous stem bark extract of Parkia biglobosa in Wistar rats. Avicenna J Phytomed 4: 59-71.

- Treit D (1984). Animal models for the study of anti-anxiety agents: a review. Neurosci Biobehav Rev 9: 203-222. [CrossRef]

- Ugwah-Oguejiofor CJ, Eze UA, Bello SO, Etuk EU, Ameh GI, Ugwah OM (2015). Anticonvulsant and sedative activities of aqueous leave extract of Leucas martinicensis (Jacq.) R. Br. NJBAS 23: 87-91. [CrossRef]
Wambebe C (1998). Development of standardized phytomedicines in Africa. J Pharm Resh Dev 3: 1-11.

World Health Organization (2001). The World Health Report. Mental Health: New Understanding, New Hope. Geneva, pp.1-15.

\section{[CrossRef]}

- Ya'u J, Abdullahi SM, Magaji MG, Yaro AH, Anuka JA, Hussaini IM (2010). Behavioral studies on the ethanol root bark extract of Carissa edulis. Jopatrot 1: 31-34.

- Ya'u J, Abdulmalik UN, Yaro AH, Chindo BA, Anuka JA, Hussaini IM (2011). Behavioral properties of Balanites aegyptiaca in rodents. $J$ Ethnopharmacol 135: 725-729. [CrossRef]

- Yaro AH, Anuka JA, Salawu OA, Hussaini IM, Usman H, Musa AM (2009). Comparative Neuropharmacological Activities Methanolic Extracts of Leaves and Roots of Cissus Cornifolia in Mice. Afr J Biomed Res 12: 219-223.

- Yaro AH, Malami S, Yau J, Sagoe CN, Anuka JA (2015a). Some behavioural studies on methanol root bark extract of Burkea africana (fabaceae) in mice. BAJOPAS 8: 216-219.

- Yaro AH, Muhammad MA, Nazifi AB, Garba MM (2015b). Butanol soluble fractions of Cissus cornifolia methanolic leaf extract and behavioural effects in mice. J Phytopharmacol 4: 202-226. [CrossRef]

- Yusuf MB, Bello B, Jaafaru IJ (2016). Anxiolytic Effect of Aqueous Root Extract of Citrus aurantium in Wistar Albino Rats. JAMPS 9: 1-9. [CrossRef] 